\title{
Erratum to: Phosphotriesterase-related protein sensed albuminuria and conferred renal tubular cell activation in membranous nephropathy
}

\author{
Chao-Wen Cheng ${ }^{1,2,3}$, Li-Chien Chang ${ }^{4}$, Tzu-Ling Tseng ${ }^{5}$, Chia-Chao Wu ${ }^{6}$, Yuh-Feng Lin ${ }^{1,7}$ and Jin-Shuen Chen ${ }^{6 *}$
}

Following publication of the article "Phosphotriesteraserelated protein sensed albuminuria and conferred renal tubular cell activation in membranous nephropathy" [1], it has come to our attention that the affiliation number 6 was incorrectly presented as: Division of Nephrology, Department of Internal Medicine, Tri-Service General Hospital, 325, Sec. 2, Cheng-Kung Rd., Neihu 114 Taipei, Taiwan, Republic of China. This should have been presented as: Division of Nephrology, Department of Internal Medicine, Tri-Service General Hospital, National Defense Medical Center, No. 325, Section 2, Cheng-Kung Road, Neihu 114 Taipei, Taiwan, Republic of China. The authors would like to sincerely apologize for any inconvenience or confusion this may have caused.

\footnotetext{
Author details

${ }^{1}$ Graduate Institute of Clinical Medicine, College of Medicine, Taipei Medical University, Taipei, Taiwan. ${ }^{2}$ Center for Translational Medicine, College of Medical Science and Technology, Taipei Medical University, Taipei, Taiwan. ${ }^{3}$ Graduate Institute of Medical Sciences, Taipei, Taiwan. ${ }^{4}$ School of Pharmacy, National Defense Medical Center, Taipei, Taiwan. ${ }^{5}$ Biomedical Technology \& Device Research Laboratories, Industrial Technology Research Institute, Hsinchu, Taiwan. 'Division of Nephrology, Department of Internal Medicine, Tri-Service General Hospital, National Defense Medical Center, No. 325, Section 2, Cheng-Kung Road, Neihu 114 Taipei, Taiwan, Republic of China. ${ }^{7}$ Department of Internal Medicine, Shuang Ho Hospital, Taipei Medical University, New Taipei, Taiwan.
}

Received: 9 March 2016 Accepted: 9 March 2016 Published online: 04 April 2016

\section{Reference}

1. Cheng CW, Chang LC, Tseng TL, Wu CC, Lin YF, Chen JS.

Phosphotriesterase-related protein sensed albuminuria and conferred renal tubular cell activation in membranous nephropathy. J Biomed Sci. 2014;21: 32. doi:10.1186/1423-0127-21-32.

\footnotetext{
* Correspondence: dgschen@ndmctsgh.edu.tw

${ }^{6}$ Division of Nephrology, Department of Internal Medicine, Tri-Service General Hospital, National Defense Medical Center, No. 325, Section 2, Cheng-Kung Road, Neihu 114 Taipei, Taiwan, Republic of China

Full list of author information is available at the end of the article
}

Submit your next manuscript to BioMed Central and we will help you at every step:

- We accept pre-submission inquiries

- Our selector tool helps you to find the most relevant journal

- We provide round the clock customer support

- Convenient online submission

- Thorough peer review

- Inclusion in PubMed and all major indexing services

- Maximum visibility for your research

Submit your manuscript at

www.biomedcentral.com/submit 